\title{
HUBUNGAN BERPIKIR KREATIF DENGAN KEMAMPUAN MENULIS \\ TEKS CERPEN SISWA KELAS XI SMA NEGERI 5 MEDAN
}

TAHUN PEMBELAJARAN 2017/2018

\author{
Oleh \\ Friska Agustya Hutabalian (friskaagust25@gmail.com) \\ Atika Wasilah, S.Pd., M.Pd. (tika_wasilah@yahoo.co.id) \\ Universitas Negeri Medan
}

\begin{abstract}
ABSTRAK
Penelitian ini bertujuan untuk mengetahui ada tidaknya hubungan berpikir kreatif dengan kemampuan menulis teks cerpen siswa kelas XI SMA Negeri 5 Medan 2017/2018.Penelitian ini termasuk penelitian korelasional.Populasi penelitian ini adalah seluruh siswa kelas XI SMA Negeri 5 Medan Tahun Pembelajaran 2017/2018 dengan sampel berjumlah 40 siswa. Pengambilan sampel menggunakan teknik cluster random sampling(acak kelas). Metode yang digunakan dalam penelitian ini adalah metode deskriptif korelasional.Dalam penelitian ini data berpikir kreatif dikumpulkan dengan tes berpikir kreatif yang menggunakan tes kreativitas verbal yang mengukur kelancaran, kelenturan, keaslian, Elabori dengan enam subtes. Masing-masing tes diberi skor 4 untuk menguraikan 4 jawaban dengan benar, skor 3 untuk menguraikan 3 jawaban dengan benar, skor 2 untuk menguraikan 2 jawaban dengan benar, skor 1 untuk menguraikan jawaban dengan benar, skor 0 untuk jawaban salah dengan rentang nilai 0100. Sedangkan data kemampuan menulis teks cerpen dikumpulkan dengan tes penugasan.

Hasil penelitian ini menunjukkan tiga hal.Pertama, kemampuan berpikir kreatiftergolong ke dalam kategori baik $(\bar{x}=79,3)$. Kedua, kemampuan menulis teks cerpen tergolong ke dalam kategori baik $(\bar{y}=$ 82,97). Ketiga, ada hubungan yang signifikan antara berpikir kreatif dengan kemampuan menulis teks cerpen siswa.Hasil penelitian yang diperoleh terdapat hubungan yang signifikan berpikir kreatif dengan kemampuan menulis teks cerpen
\end{abstract}

Kata Kunci: kemampuan, berpikir kreatif, menulis, teks cerpen

\section{PENDAHULUAN}

Pengetahuan adalah hal yang sangat penting di era modern ini.Dapat kita akui, dari pandangan kita pada kondisi kehidupan kita saat ini kehidupan semakin rumit, semakin canggih dan dituntut harus tanggap.Perubahan zaman yang dilalui dengan persaingan yang ketat menuntut manusia untuk mempunyai kesiapan yang 
tinggi, sehingga apapun yang dihadapi dapat dilaksanakan tanpa adanya keraguraguan. Sejalan dengan hal di atas, mengenai isi Undang-Undang Nomor 20 Tahun 2003 Bab II Pasal 3 tentang fungsi pendidikan nasional adalah untuk dikembangkannya kemampuan dan membentuk watak serta peradaban bangsa yang bermartabat dalam rangka mencerdaskan kehidupan bangsa, bertujuan untuk berkembangnya potensi peserta didik agar menjadi manusia yang beriman dan bertakwa kepada Tuhan Yang Maha Esa, berakhlak mulia, sehat, berilmu, cakap, kreatif, mandiri, dan menjadi warga negara yang demokratis serta bertanggung jawab.Dalam hal mencapai ilmu pengetahuan yang berguna bagi masa depan, diperlukan adanya tindakan berpikir untuk memperolehnya. Menurut Edward De Bono (1977:10) ada enam berpikir, salah satunya adalah berpikir kreatif. Munandar (2012:68) kreativitas atau berpikir kreatif secara operasional dirumuskan sebagai suatu proses yang tercemin dari kelancaran, kelenturan, dan orisinalitas dalam berpikir.

Dalam kurikulum 2013, dirasa sangat cocok untuk membiasakan siswa untuk berpikir kreatif karena berbeda dengan kurikulum sebelumnya, yang pembelajaran berpusat pada guru, pada kurikulum 2013 ini proses belajar mengajarkan berpusat pada siswa. Jelas pada kurikulum ini guru sebagai fasilitator, selebihnya siswa yang mengali secara lebih pengetahuan itu sendiri. Pada bagian itulah siswa dituntut dalam kegiatan proses belajar mengajar menjadi siswa yang aktif, kreatif serta inovatif dalam mencari ilmu pengetahuan.Bila kita lihat sepintas, siswa-siswa Indonesia adalah siswa-siswa yang kreatif namun, ternyata kemampuan berpikir kreatif siswa-siswa Indonesia secara umum masih tergolong rendah. Hal ini sejalan dengan Munandar (2012:66) menyatakan bahwa hasil tes kreativitas yang dilakukan oleh Jellen dan Urban dengan sampel anak dari delapan negara, termasuk Indonesia. Anak Indonesia mencapai skor kreativitas paling rendah dibandingkan dengan negara-negara lain, diantaranya Filipina, India, dan Afrika Selatan.Siswa yang diteliti adalah siswa dari sekolah pembangunan di Jakarta dengan mutu yang cukup baik dan sekolah tersebut menerapkan modul sistem pembelajaran yang memungkinkan siswa belajar mandiri. 
Sehubung dengan hal yang diatas, Bahasa Indonesia adalah pembelajaran yang lumayan berkaitan dengan nilai seni atau pun kreatif. Karena di dalam pembelajaran Bahasa Indonesia terdapat hasil produk sastra.Untuk itu tidak dapat kita hindarkan pengajaran terhadap siswa dengan pengembangan potensi kreativitas. Hal ini sejalan dengan pendapat Wellek (dalam Ambarita 2009:118) yang menyatakan bahwa sastra sebagai bagian integral materi pelajaran di sekolah, sebagai suatu kreasi dan seni yang dapat menyentuh pribadi kehidupan manusia, menunjang keterampilan, meningkatkan pengetahuan budaya, mengembangkan rasa karsa, serta membentuk watak. Karena sastra sesuai dengan sifatnya yang imajinatif yang dapat mengembangkan dan membangun potensi kreatif dalam diri.Ambarita (2009:119) menyakini bahwa sastra sebagai suatu produk kreatif yang dapat mengembangkan potensi kreativitas siswa.

Terlebih lagi pada pembelajaran Bahasa Indonesia dalam kurikulum 2013 menggunakan pembelajaran berbasis teks baik secara lisan maupun tulisan.Namun terlepas dari itu, pada dasarnya setiap orang yang belajar bahasa dituntut untuk menguasai empat aspek keterampilan berbahasa yaitu (1) menyimak, (2) berbicara, (3) membaca, dan (4) menulis.Dari tulisan kita dapat menemukan gambaran diri dari hasil tulisannya.Aspek keterampilan berbahasa yang tidak kalah pentingnya ialah keterampilan menulis.Karena banyak pula yang menyatakan bahwa seseorang dapat dinilai dari tulisannya.Tentu semakin banyak hasil karya tulisan yang telah seseorang hadirkan maka bisa jadi semakin tajam potensi berpikir kreatif Karena menulis sendiri mempunyai manfaat untuk mengembangkan kebiasaan berpikir kreatif dan motivasi untuk belajar secara kontiniu. Dengan kata lain tentu ada hubungan antara berpikir kreatif dengan mengikuti kegiatan besastra. Salah satu dari kegiatan besastra adalah menulis cerpen, Menulis cerpen ialah tahap yang paling sederhana dalam menulis.

Berdasarkan uraian di atas, maka penulis tertarik untuk meneliti sejauh mana "Hubungan Berpikir Kreatif dengan Kemampuan Menulis Cerpen Siswa Kelas XI SMA Negeri 5 Medan Tahun Pembelajaran 2017/2018.” 


\section{METODE PENELITIAN}

Metode penelitian adalah cara yang digunakan oleh peneliti dalam mengumpulkan data penelitiannya (Arikunto 2006:160). Dengan begitu metode juga merupakan cara yang utama mencapai tujuan untuk mengkaji hipotesis dengan menggunakan alat dan teknik.

Sesuai dengan masalah dan tujuan penelitian yaitu untuk melihat hubungan kemampuan berpikir kreatif dengan kemampuan menulis cerpen, maka metode yang digunakan dalam penelitian ini adalah metode deskriptif korelasional.Hal ini sejalan dengan pendapat Arikunto (2006:270), penelitian korelasi bertujuan untuk menemukan ada tidaknya hubungan dan apabila ada, berapa eratnya hubungan serta berarti atau tidak hubungan itu.

\section{HASIL PENELITIAN DAN PEMBAHASAN}

\section{Hasil Penelitian Berpikir Kreatif dengan Kemampuan Menulis Teks Cerpen}

\section{Spesifikasi Tes}

\section{a. Tujuan Tes}

Pada penelitian ini, bentuk tes berpikir kreatif yang dilakukan ialah tes kreativitas verbal yang dilakukan dengan maksud untuk mengetahui sejauh manakah kemampuan berpikir kreatif siswa.Bentuk tes menulis teks cerpen ialah dilakukan dengan bentuk tes penugasan yang dilakukan dengan maksud untuk mengetahui kemampuan menulis teks cerpen.Hasilnya digunakan untuk melihat ada tidaknya hubungan antara berpikir kreatif dengan kemampuan menulis teks cerpen.

\section{b. Instrumen}

Dalam kemampuan berpikir kreatif, tesyang digunakan ialah menggunakan tes kreativitas verbal yang merujuk pada penilaian menurut Bessemer dan Treffinger dalam Munandar (2012 : 41) yang menyatakan produk kreatif dapat digolongkan menjadi empat kategori yang miliputi kelancaran, kelenturan, keaslian, elaborasi yang dijabarkan dengan enam subtes. Keenam subtes tersebut ialah permulaan kata, menyusun kata, membentuk kalimat 3 kata, sifat-sifat yang sama, macam-macam penggunaan, dan apa akibatnya. 
Tabel 1. Ketentuan Waktu Pengisian

\begin{tabular}{|l|l|c|c|c|}
\hline No & Nama Tes & $\begin{array}{l}\text { Jumlah } \\
\text { Butir }\end{array}$ & $\begin{array}{l}\text { Waktu/ } \\
\text { Butir } \\
\text { (Menit) }\end{array}$ & $\begin{array}{l}\text { Total } \\
\text { Waktu } \\
\text { (menit) }\end{array}$ \\
\hline 1 & Permulaan Kata & 4 & 1 & 4 \\
\hline 2 & Menyusun Kata & 4 & 2 & 8 \\
\hline 3 & Membentuk kalimat 3 kata & 4 & 3 & 12 \\
\hline 4 & Sifat-sifat yang sama & 4 & 2 & 8 \\
\hline 5 & Macam-macam penggunaan & 4 & 2 & 8 \\
\hline 6 & Apa akibatnya & 5 & 4 & 20 \\
\hline & Jumlah & 25 & & 60 \\
\hline
\end{tabular}

Dalam menulis teks cerpen, dikumpulkan data dengan menggunakan tes penugasan dengan cara menugaskan siswa untuk menulis cerpen sesuai dengan kemampuan imajinasi siswa.

\section{c. Bentuk Tes}

Penelitian ini menggunakan tes berpikir kreatif bentuk tes non-objektif uraian serta menulis teks cerpen menggunakan tes penugasan menulis.

\section{d. Panjang Tes}

Pada tes berpikir kreatif menggunakan waktu yang telah ditentukan sesuai pada tiap butir subtes soal yaitu 60 menit.Pada kemampuan menulis teks cerpen, pada umumnya waktu yang dibutuhkan untuk mengerjakan tes penugasan menulis ialah 90 menit.

\section{PEMBAHASAN}

\section{Analisis data yang dilakukan meliputi hubungan kemampuan berpikir} kreatif dengankemampuan menulis teks cerpen.

\section{Kemampuan Berpikir Kreatif}

Berdasarkan data yang diperoleh dari hasil penelitian dengan jumlah responden sebanyak 40 orang, terdapat nilai tertinggi 89 dan nilai terendah 60 dengan rata-rata $(M)=79,3$ dan standar deviasi $(S D)=6,7$ 
Tabel 2. Distribusi Frekuensi Data Variabel Berpikir Kreatif

\begin{tabular}{|c|c|c|c|}
\hline Kelas & Kelas Interval & F. Absolut & F. Relatif \\
\hline 1 & $60-64$ & 2 & $5 \%$ \\
\hline 2 & $65-69$ & 1 & $2,5 \%$ \\
\hline 3 & $70-74$ & 5 & $12,5 \%$ \\
\hline 4 & $75-79$ & 11 & $27,5 \%$ \\
\hline 5 & $80-84$ & 10 & $25 \%$ \\
\hline 6 & $85-89$ & 11 & $27,5 \%$ \\
\hline \multicolumn{2}{|r|}{ Jumlah }
\end{tabular}

Maka sesuai dengan kategori penilaian pada bab sebelumnya dapat dilihat kemampuan berpikir kreatif siswa SMA Negeri 5 Medan berkategori baik dengan rincian persentase pada tabel di bawah ini

Tabel 3.Rincian Persentase Data Berpikir Kreatif

\begin{tabular}{|c|c|c|c|}
\hline Skor & Kategori Nilai & Frekuensi & Persentase \\
\hline $86-100$ & Baik Sekali & 8 & $20 \%$ \\
\hline $76-85$ & Baik & 20 & $50 \%$ \\
\hline $56-75$ & Cukup & 12 & $30 \%$ \\
\hline $10-55$ & Kurang & - & - \\
\hline \multicolumn{2}{|r|}{} & 40 & $100 \%$ \\
\hline
\end{tabular}

Bila kita lihat dari persentase skor kemampuan berpikir kreatif dalam menjawab setiap subtes, terdapat sebanyak $94,53 \%$ dalam menjawab subtes 1 , terdapat sebanyak $86,56 \%$ dalam menjawab subtes 2 , terdapat sebanyak $70,62 \%$ dalam menjawab subtes 3 , terdapat sebanyak $91,71 \%$ dalam menjawab subtes 4 , terdapat sebanyak $57,34 \%$ dalam menjawab subtes 5 dan terdapat sebanyak $76,12 \%$ dalam menjawab subtes 6. Berdasarkan data persentase yang ada, kemampuan siswa dalam menjawab subtes 5 adalah yang paling rendah.Subtes 5 ialah subtes yang berkaitan mengukur keaslian.

\section{Kemampuan Menulis Teks Cerpen}

Berdasarkan data yang diperoleh dari hasil penelitian dengan jumlah responden sebanyak 40 orang, terdapat nilai tertinggi 96 dan nilai terendah 70 dengan rata-rata $(\mathrm{M})=82,97$ dan standar deviasi $(\mathrm{SD})=7,2$. 
Tabel 4. Distribusi Frekuensi Data Variabel Menulis Teks Cerpen

\begin{tabular}{|c|c|c|l|}
\hline Kelas & Interval & F. Absolut & \multicolumn{1}{|c|}{ F.Relatif } \\
\hline 1 & $70-74$ & 6 & $15 \%$ \\
\hline 2 & $75-79$ & 6 & $15 \%$ \\
\hline 3 & $80-84$ & 11 & $27,5 \%$ \\
\hline 4 & $85-89$ & 9 & $22,5 \%$ \\
\hline 5 & $90-94$ & 5 & $12,5 \%$ \\
\hline 6 & $95-99$ & 3 & $7,5 \%$ \\
\hline \multicolumn{2}{|l}{ Jumlah } & $\mathbf{4 0}$ & $\mathbf{1 0 0 \%}$ \\
\hline
\end{tabular}

Maka sesuai dengan kategori penilaian pada bab sebelumnya dapat dilihat kemampuan menulis teks cerpen siswa SMA Negeri 5 Medan berkategori baik dengan rincian persentase pada tabel di bawah ini

Tabel 5. Rincian Persentase Data Menulis Teks Cerpen

\begin{tabular}{|c|c|c|c|}
\hline Skor & Kategori Nilai & Frekuensi & Persentase \\
\hline $86-100$ & Baik Sekali & 14 & $35 \%$ \\
\hline $76-85$ & Baik & 20 & $50 \%$ \\
\hline $56-75$ & Cukup & 6 & $15 \%$ \\
\hline $10-55$ & Kurang & - & - \\
\hline \multicolumn{2}{|r|}{} & 40 & $100 \%$ \\
\hline
\end{tabular}

Selain itu pemahaman siswa tentang teks cerpen juga baik, hal ini terlihat dari sebagian besar cerpen yang dihasilkan siswa sudah memenuhi kriteria penilaian dalam menulis teks cerpen.Ketika menulis teks cerpen, siswa juga benar-benar mengarahkan diri untuk berkonsentrasi agar dapat menciptakan teks cerpen yang baik.

Dalam kemampuan menulis teks cerpen ini ada lima aspek yang harus diperhatikan siswa yang meliputi organisasi kelengkapan unsur, isi, kosakata, penggunaan bahasa, dan mekanik atau aturan penulisan.

\section{Hubungan Berpikir Kreatif dengan Kemampuan Menulis Teks Cerpen}

Pengujian Hipotesis dilakukan dengan korelasi product moment $\left(\mathrm{r}_{\mathrm{xy}}\right)$.Dari perhitungan korelasi product moment dengan angka kasar diperoleh koefisien korelasi antara $\mathrm{X}$ dan $\mathrm{Y}$ sebesar 0.71 , sedangkan rtabel dengan $\mathrm{N}=40$ dan taraf signifikan 5\% sebesar 0,321. Dengan demikian harga $r_{x y}>r_{\text {tabel }}(0,71>0,321)$. 
Oleh karena itu, hipotesis penelitian yang mengatakan bahwa terdapat hubungan yang signifikan antara Berpikir Kreatif (X) Terhadap Kemampuan Menulis Teks Cerpen (Y), dapat diterima dan teruji kebenarannya.MenurutSugiyono (2016:184), besarannya tergolong kuat karena berada dalam rentang antara 0,60 - 0,799.Jadi dapat disimpulkan bahwa pada taraf signifikan 0,05 terdapat hubungan yang signifikan antara berpikir kreatif (X) dengan kemampuan menulis teks cerpen (Y) dengan kekuatan korelasi kuat.Artinya semakin baik berpikir kreatifnya maka kemampuan menulis teks cerpen semakin baik pula. Kemampuan menulis teks cerpen tidak terlepas dari kemampuan berpikir kreatif.

Kemampuan berpikir kreatifberhubungan dengan kemampuan menulis teks cerpen adalah sebesar $71 \%$ dan sisanya $29 \%$ ditentukan oleh faktor lain. Hal tersebut menunjukkan eratnya hubungan kedua variabel tersebut, gambaran hubungan tersebut menunjukkan bahwa berpikir kreatif mempunyai pengaruh yang besar terhadap kemampuan menulis teks cerpen siswa. Hal ini dapat pula kita lihat pada hasil lembar kerja siswa dalam menjawab tes berpikir kreatif, siswa paling lemah dalam menjawab subtes 5 .Subtes 5 ialah subtes yang berkaitan dengan mengukur keaslian.Munandar (2012:69) mengatakan bahwa pada subtes ini subjek harus memikirkan sebanyak mungkin penggunaan yang tidak lazim (tidak biasa) dari benda sehari-hari, karena dalam subtes ini subjek harus melepaskan diri dari kebiasaan melihat benda sebagai alat untuk melakukan hal tertentu saja. Hal ini berdampak pada hasil kerja siswa dalam menulis teks cerpen, bahwa sebanyak 11 siswa atau 27,5\% memiliki tema percintaan, sebanyak 19 siswa atau 47,5\% memiliki tema persahabatan, dan sebanyak 10 siswa atau $25 \%$ memiliki tema yang terlepas dari percintaan dan persahabatan seperti tema tentang penyelidikan terhadap kejahatan, insiprasi kehidupan, dan lain sebagainya. Dalam penulisan cerpen, tema ialah berkenaan dengan ide dari cerita.Berdasarkan informasi diatas terlihat bahwa siswa masih belum bervariasi dalam menuangkan tema cerita, siswa masih mengambil ide yang lazim atau yang sering dituliskan dalam cerita pendek. 
Terlihat pula, skor siswa dalam menjawab berpikir kreatif yang paling tinggi ialah pada subtes 1 yaitu yang berkaitan dengan kelancaran.Munandar (2012:68) menyatakan bahwa tes ini mengukur kelancaran dengan kata, yaitu kemampuan untuk menemukan kata yang memenuhi persyaratan structural.Hal ini berdampak pada kemampuan menulis teks cerpen siswa, dinyatakan telah mampu memilih kata-kata yang membuat cerpen terlihat baik, namun tentu perlu ada peningkatan kosakata yang lebih baik lagi.

Hal ini sesuai dengan pernyataan terdahulu pada kerangka konseptual, bahwa baik kemampuan berpikir kreatif siswa tersebut maka semakin baik pula kemampuan menulis teks cerpen.

\section{PENUTUP}

\section{Kesimpulan dan Saran}

\section{Kesimpulan}

1. Kemampuan berpikir kreatif siswa kelas XI SMA Negeri 5 Medan Tahun Pembelajaran 2017/2018 cenderung baik. Hal ini dapat diketahui dari 40 orang siswa, adalah 8 orang (20\%) kategori baik sekali, 20 orang (50\%) kategori baik, 12 orang (30\%) kategori cukup.

2. Kemampuan menulis teks cerpen siswa kelas XI SMA Negeri 5 Medan Tahun Pembelajaran 2017/2018 cenderung baik. Hal ini dapat diketahui dari 40 orang siswa, 14 orang (35\%) kategori baik sekali, 20 orang (50\%) kategori baik, 6 orang (15\%) kategori cukup.

3. Terdapat korelasi yang signifikan antara kemampuan berpikir kreatif dengan kemampuan menulis teks cerpen. Adapun besar koefisien $r_{x y}=$ 0,71 . Hal ini berarti bahwa $71 \%$ kemampuan berpikir kreatif berkorelasi dengan kemampuan menulis teks cerpen siswa kelas XI SMA Negeri 5 Medan Tahun Pembelajaran 2017/2018

\section{Saran}

1. Dilihat dari hasil kemampuan berpikir kreatif siswa yang cenderung baik, ternyata potensi berpikir kreatif teradapat dalam diri masing-masing siswa 
maka hendaknya sekolah terutama guru mampu lebih baik lagi dalam upaya meningkatkan, melatih serta memberikan kesempatan bagi siswa untuk mengembangkan potensi daya pikir para siswa, serta kebebasan dalam berpikir sehingga akan tercipta kreativitas.

2. Dilihat dari hasil kemampuan menulis cerpen siswa cenderung baik. Siswa dikategorikan sudah mampu dalam menulis cerpen hanya perlu selalu ada peningkatan. Selaras dengan hal itu, menulis cerpen juga merupakan salah satu cara sebagai budaya literasi, untuk itu guru hendaknya lebih terampil dan sering melatih siswa dalam hal penciptaan cerpen serta memberi kesempatan pada siswa untuk mampu mengembangkan ide-ide kreatif sehingga kiranya mampu menciptakan cerpen yang bernilai estetik tinggi menyaingi cerpen karya sastrawan.

3. Kemudian, perlu kiranya diadakan penelitian lebih lanjut dan lebih mendalam dai penelitian ini untuk mencari hubungan yang lebih spesifik serta melihat perubahan yang terjadi pada siswa yang bersangkutan.

\section{DAFTAR PUSTAKA}

Arikunto, Suharsimi. 2006. Prosedur Penelitian Pendekatan Suatu Pratik. Jakarta: Rineka Cipta.

Arnita. 2013. Pengantar Statistka. Bandung: Citapustaka Media Perintis.

Barus, Sanggup. 2013. Penulisan Karya Tulis. Jakarta: Halaman Moeka

De Bono, Edward. 1977. Berpikir Praktis. Binarupa aksara. Jakarta

Rahmayati, Hirza. 2013. Hubungan Berpikir Kreatif dengan Kemampuan Menulis Siswa Kelas X SMA Taman Siswa Tahun Pembelajaran 2012/2013.Skripsi. Medan UNIMED

Munandar, Utami. 2012. Pengembangan Kreativitas Anak Berbakat. Jakarta: Rineka Cipta

Nurgiyantoro, Burhan. 2014. Penilaian Pembelajaran Bahasa. Yogyakarta. BPFE-Yogyakarta

Roekhan. 1991. Menulis Kreatif. Malang: YA3 
Rokhmansyah, Alfian. 2014. Studi dan pengkajian sastra. Yogyakarta: Graha Ilmu

Setiawan, Hengki. 2013. Paspor Kreatif. Yogyakarta: CV ANDI

Sudarma, Momon. 2013. Pengembangan Keterampilan Berpikir Kreatif. Jakarta: Raja Grafindo Persada

Sugiyono. 2016. Metode Penelitian Pendidikan. Bandung : Alfabeta

Supratman dan Yani. 1999. Inti sari sastra Indonesia. Bandung: Cv Pustaka Setia

Toha sarumpaet, Riris. 2002. Sastra Masuk Sekolah. Indonesia Magelang: Tera

Wheeler, Jim. 2004. The Power of Innovative Thingking, Mengoptimlakan Ide-ide Baru dan Kreativitas untuk memperlancar kesuksesan. Jakarta: PT Elex Media Komputindo

Sumber lain:

Hepitriati.2014. Profil Kemampuan Berpikir Kritis dan Kreatif Siswa Kelas XI IPA SMAN Kota Bengkulu Tahun Ajaran 2013/2014, Skripsi, www google.com (diakses 10 Juni 2017).

Martina, Novra. 2014. Kemampuan Menulis Cerita Pendek Menggunakan Media Gambar Siswa Kelas X Madrasah Aliyah Negeri Tanjung Pinang, Jurnal Penelitian, www google.com (diakses 25 Februari 2017) 